\title{
ANALISIS TRANSIEN PADA SISTEM TRANSMISI 150 KV RIAU SETELAH BEROPERASINYA PLTU TENAYAN RAYA MENGGUNAKAN POWERWORLD SIMULATOR
}

\author{
Indra Gunawan ${ }^{1}$, Hamzah Eteruddin ${ }^{2}$, Usaha Situmeang ${ }^{3}$ \\ ${ }^{1,2,3}$ Program Studi Teknik Elektro, Fakultas Teknik, Universitas Lancang Kuning Pekanbaru. \\ Jl. Yos Sudarso km. 8 Rumbai, Pekanbaru, Telp. (0761) 52324 \\ E-mail: boyindra66@gmail.com, hamzah@unilak.ac.id, usahasitumeang@unilak.ac.id
}

\begin{abstract}
ABSTRAK
Dalam proses penyaluran energi listrik kestabilan sistem merupakan hal yang sangat penting. Salah satu masalah dalam kualitas daya yaitu stabilitas transien. Riau merupakan salah satu provinsi yang ada di Indonesia, dengan luas wilayah $87.023,66 \mathrm{~km}^{2}$. Pertumbuhan jumlah penduduk provinsi Riau sangat besar yaitu pada tahun 2016 sebesar 6.500.971 jiwa dan tahun 2017 meningkat menjadi 6.657.911 jiwa. Riau defisit energi listrik sebesar 270 MW dari kebutuhan listrik 600 MW. Dalam upaya untuk memenuhi kebutuhan listrik maka sistem transmisi Riau telah mengoperasikan Pembangkit Listrik Tenaga Uap (PLTU) Tenayan Raya. Dengan penambahan ini perlu dilakukan kajian mengenai kestabilan transien yang terjadi pada sistem. Analisa dilakukan pada saat terjadi gangguan hubung singkat 3 phasa untuk melihat respon sudut rotor generator menggunakan software Powerworld Simulator 20. Pada saat gangguan hubung singkat 3 phasa terjadi pada ujung sisi kirim saluran transmisi dari gardu induk Tenayan Raya menuju gardu induk Teluk Lembu diperoleh waktu pemutus sebesar 0,29 detik dengan sudut pemutus kritis $108,6266^{\circ}$. Hasil simulasi menggunakan powerworld simulator diperoleh waktu pemutus maksimum 0,36 detik. Jarak titik gangguan berbanding lurus dengan waktu dan sudut pemutus kritis, semakin jauh titik gangguan pada saluran transmisi maka semakin besar sudut pemutus kritis.
\end{abstract}

Kata kunci : Kualitas Daya, Stabilitas Transien, Hubung Singkat 3 Phasa

\section{ABSTRACT}

In the process of distributing electrical energy the stability of the system is very important. One problem in power quality is transient stability. Riau is one of the provinces in Indonesia with an area of $87,023.66 \mathrm{~km}^{2}$, and has a very large population growth which is from 6,500,971 people in 2016 to 6,657,911 in 2017. Therefore the need for electrical energy is very large. Riau has a defisit of electrical energy of $270 \mathrm{MW}$ from electricity needs of $600 \mathrm{MW}$. In an effort to meet electricity needs, the Riau transmission system has operated a Steam Power Plant (PLTU) in the Tenayan Raya region. With this addition, it is necessary to study the transient stability that occurs in the system. The analysis was carried out when there was a 3-phase short circuit disturbance to see the generator rotor angle response using Powerworld Simulator 20 software. When a 3-phase short circuit interference occured at the end of the transmission line from the Tenayan Raya substation to Teluk Lembu substation the breaker time was 0.29 seconds with a critical breaker angle of $108.6266^{\circ}$. From the simulation results using the powerworld simulator, it is proven that the maximum breaker time is 0.36 seconds. The point of disturbance is directly proportional to the time and angel of the critical breaker, the farther the point of interference on the transmission line, the greater the critical breaker angle.

Keyword: Power Quality, Transient stability, 3 - phase short circuit

\section{PENDAHULUAN}

Dalam proses penyaluran energi listrik perlu adanya kestabilan kualitas daya. Power Quality (Kualitas Daya) merupakan salah satu persoalan dalam sistem tenaga listrik, persoalan ini meliputi perubahan bentuk tegangan maupun perubahan frekuensi yang dapat mengakibatkan terjadinya kegagalan operasi pada peralatan [1]. Dalam proses penyaluran energi listrik kestabilan sistem merupakan hal yang sangat penting, kestabilan yang baik bertujuan untuk dapat melayani konsumen secara kontinyu. Kestabilan yang baik tersebut adalah bagaimana suatu sistem tenaga listrik dapat memenuhi dan melayani beban secara stabil dan terus menerus dengan tegangan yang stabil, serta dapat memenuhi standar yang berlaku. 
Riau merupakan salah satu provinsi yang ada di Indonesia. Dari data Badan Pusat Statistik provinsi Riau memiliki luas $87.023,66 \mathrm{~km}^{2}$ dan dengan jumlah penduduk pada tahun 2016 sebesar 6.500.971 jiwa, tahun 2017 sebesar 6.657.911 jiwa, tahun 2018 sebesar 6.814.909 jiwa, dan pada tahun 2019 sebesar 6.971.745 jiwa [2]. Dengan pertumbuhan ini sekitar 2,3\% akan dibutuhkan energi listrik sangat besar.

Menurut surat kabar Tribun Pekanbaru pihak PLN menyatakan Riau defisit energi listrik sebesar 270 MW dari kebutuhan listrik 600 MW [3]. Dalam upaya untuk memenuhi kebutuhan listrik maka Unit Pelayanan Transmisi (UPT) Pekanbaru telah mengoperasikan Pembangkit Listrik Tenaga Uap (PLTU) Tenayan Raya. Dengan penambahan ini perlu dilakukan kajian mengenai kestabilan transien yang terjadi pada sistem [4]-[8].

Masalah pada sistem tenaga listrik yang sering muncul adalah masalah yang berkaitan dengan dinamika dan stabilitas sistem untuk merespon gangguan yang terjadi, karena masalah dinamika dan stabilitas sistem tersebut sangat berkaitan erat dengan unjuk kerja sistem yang mencerminkan kondisi setiap saat, baik kondisi normal maupun kondisi gangguan, serta pemulihannya [9]. Stabilitas sistem tenaga listrik didefinisikan sebagai suatu keadaan sistem untuk kembali lagi ke keadaan normal atau stabil setelah mengalami gangguan [10]-[12].

Stabilitas sistem tenaga adalah kemampuan sistem tenaga listrik untuk kondisi operasi awal yang diberikan, untuk mendapatkan kembali keadaan kestabilan operasi setelah terjadi gangguan, dengan sebagian besar variabel sistem dibatasi sehingga praktis seluruh sistem tetap utuh [13].

\section{METODE PENELITIAN}

Masalah pada sistem tenaga listrik yang sering muncul adalah masalah yang berkaitan dengan dinamika dan stabilitas sistem untuk merespon gangguan yang terjadi, karena masalah dinamika dan stabilitas sistem tersebut sangat berkaitan erat dengan unjuk kerja sistem yang mencerminkan kondisi setiap saat, baik kondisi normal maupun kondisi gangguan, serta pemulihannya. Stabilitas sistem tenaga listrik didefinisikan sebagai suatu keadaan sistem untuk kembali lagi ke keadaan normal atau stabil setelah mengalami gangguan. Gangguan pada sistem tenaga listrik dapat menimbulkan osilasi tegangan, frekuensi dan daya. Oleh karena itu perlu pengaturan agar osilasi yang terjadi segera kembali ke kondisi normal.

\section{Stabilitas Sistem Tenaga}

Stabilitas steady state merupakan kemampuan sistem tenaga listrik untuk mempertahankan keadaan sinkron antara mesin terhadap gangguan kecil, yaitu gangguan kecil/perlahan yang merupakan fluktuasi beban normal rata-rata. Gangguan ini dapat diatasi oleh regulator tegangan (AVR) dan governor turbin secara otomatis. Namun bila batas power transfer dilampaui, mesin akan kehilangan sinkron. Selain itu kondisi lepas sinkron dapat terjadi apabila secara tiba-tiba ada beban besar yang dipasang atau dilepas. Dengan perubahan yang cepat atau pembebanan yang tiba-tiba tersebut, akan menyebabkan terjadinya goncangan pada sistem tenaga listrik [6].

Sedangkan berdasarkan paper IEEE definition and classification of power system stability klasifikasi kestabilan sistem tenaga listrik dapat dibedakan menjadi tiga katagori, yaitu [13] :

1. Kestabilan sudut rotor

2. Kestabilan frekuensi

3. Kestabilan tegangan

\section{Kriteria Sama Luas Pada Stabilitas}

Kriteria sama luas tidak dapat digunakan secara langsung dalam sistem dimana tiga atau lebih mesin diwakili. Meskipun fenomena fisik diamati pada masalah dua mesin pada dasarnya sama seperti dalam kasus multimachine. Namun, keakuratan dari perhitungan numerik meningkat dengan jumlah mesin dipertimbangkan dalam studi stabilitas transien [14].

Dengan menggabungkan perilaku dinamis generator sebagaimana didefinisikan oleh persamaan ayunan, dengan hubungan sudut-daya, digunakan untuk menggambarkan konsep stabilitas sementara menggunakan kriteria luas yang sama seperti pada Gambar 1 dan hubungan sudut daya ketika satu saluran lepas seperti Gambar 2 [15], [16].

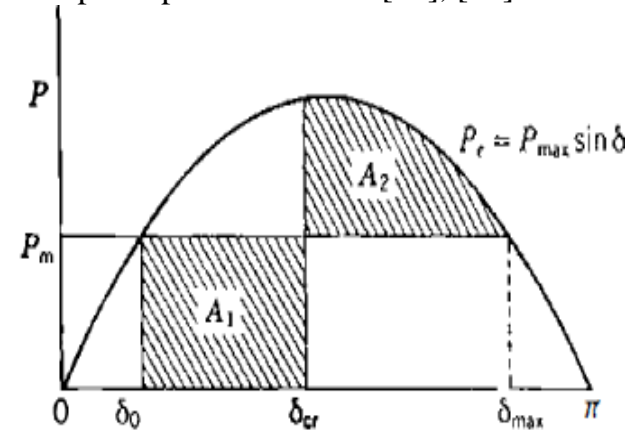

Gambar 1. Kurva kriteria sama luas

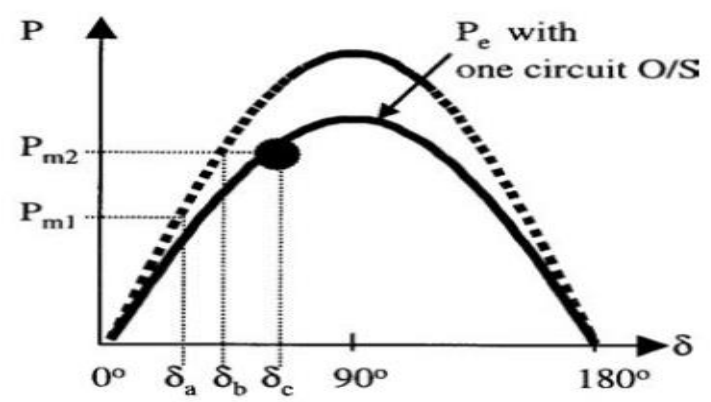

Gambar 2. Hubungan sudut daya ketika satu saluran lepas

Perhitungan Sudut Dan Waktu Pemutus Kritis

Dalam kasus tertentu baik sudut pemutus kritis 
maupun waktu pemutus kritis dapat dihitung [14].

$$
A_{1}=\int_{\delta_{0}}^{\delta_{c r}} P_{m} d \delta=P_{m}\left(\delta_{c r}-\delta_{0}\right)
$$

Jika area $\mathrm{A}_{2}$ adalah

$$
\begin{aligned}
A_{2} & =\int_{\delta_{c r}}^{\delta_{\max }}\left(P_{\max } \sin \delta-P_{m}\right) d \delta \\
& =P_{\max }\left(\cos \delta_{c r}-\cos \delta_{\max }\right)\left(\delta_{\max }-\delta_{c r}\right)
\end{aligned}
$$

Dengan menyatakan rumus-rumus $A_{1}$ dan $A_{2}$, dengan memindahkan suku-sukunya, maka diperoleh sudut pemutus kritis pada ujung sisi kirim seperti Gambar 3 [14].

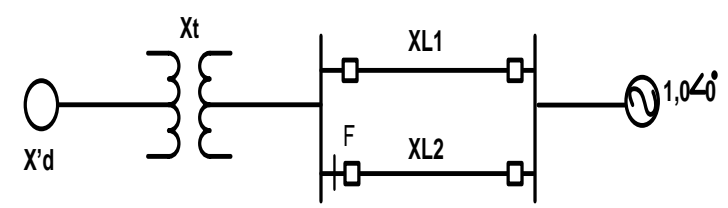

Gambar 3. Single line sistem gangguan dititik F

$\cos \delta_{c r}=\left(P_{m} / P_{\text {maks }}\right)\left(\delta_{\text {maks }}-\delta_{0}\right)+\cos \delta_{\text {maks }}$

Rangkaian untuk menentukan reaktansi sistem saat gangguan hubung singkat 3 phasa pada tengah saluran transmisi seperti Gambar 4.

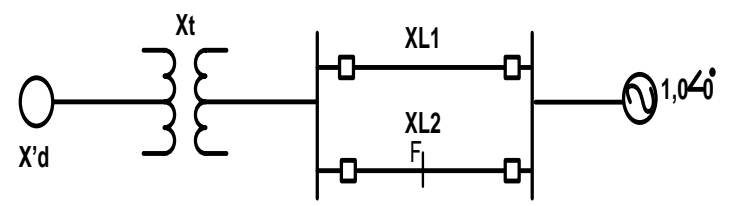

Gambar 4. Single line sistem gangguan dititik F

$$
X_{\text {Sebelum gangguan }}=X^{\prime}{ }_{d}+X_{T}+\frac{X_{L}}{2}
$$

Rangkaian reaktansi saluran transmisi pada saat gangguan hubung singkat 3 phasa seperti gambar diatas ditransformasikan $\Delta-\mathrm{Y}[17]$.

$$
\begin{aligned}
& X_{A}=\frac{\left(X_{L 1}\right)\left(X_{L 2} / 2\right)}{\left(X_{L 1}\right)+\left(X_{L 2} / 2\right)+\left(X_{L 2} / 2\right)} \\
& X_{B}=\frac{\left(X_{L 1}\right)\left(X_{L 2} / 2\right)}{\left(X_{L 1}\right)+\left(X_{L 2} / 2\right)+\left(X_{L 2} / 2\right)} \\
& X_{C}=\frac{\left(X_{L 2} / 2\right)\left(X_{L 2} / 2\right)}{\left(X_{L 1}\right)+\left(X_{L 2} / 2\right)+\left(X_{L 2} / 2\right)} \\
& X_{D}=X^{\prime}{ }_{d}+X_{T}+X_{A}
\end{aligned}
$$

Sehingga nilai reaktansi selama gangguan ditulis [17].

$$
X_{\text {Selama Gangguan }}=\frac{\left(X_{B}\right)\left(X_{C}\right)+\left(X_{B}\right)\left(X_{D}\right)+\left(X_{D}\right)\left(X_{C}\right)}{\left(X_{C}\right)}
$$

Dan nilai reaktansi setelah gangguan diperoleh [17].

$$
X_{\text {Sesudah Gangguan }}=X_{d}^{\prime}+X_{T}+X_{L 1}
$$

Jika nilai reaktansi sebelum dan sesudah gangguan telah didapatkan, Kemudian untuk menentukan nilai $r_{1}$ dan $r_{2}$ dihitung menggunakan persamaan [17].

$$
\begin{aligned}
& r_{1}=\frac{X_{\text {Sebelum Gangguan }}}{X_{\text {Selama Gangguan }}} \\
& r_{2}=\frac{X_{\text {Sebelum Gangguan }}}{X_{\text {Sesudah Gangguan }}}
\end{aligned}
$$

Maka nilai sudut pemutus kritis pada saat gangguan berada jauh dari sisi kirim dapat dihitung dengan persamaan [17].

$\delta_{c r}=\cos ^{-1} \frac{\left(\frac{P m}{P m a k}\left(\delta_{m a k}-\delta_{0}\right)+r_{2} \cos \delta_{m a k}-r_{1} \cos \delta_{0}\right)}{r_{2}-r_{1}}$

Kita lihat dari lengkungan sudut daya sinusiodal bahwa [17].

$$
\delta_{\text {maks }}=\left(\pi-\delta_{0}\right) \text { radian }
$$

Maka dapat dihitung waktu pemutus kritis $\left(t_{c r}\right)$ [17].

$$
t_{c r}=\sqrt{\frac{4 H\left(\delta_{c r}-\delta_{0}\right)}{\omega_{s} P_{m}}}
$$

Keterangan :

$P_{m} \quad=$ Daya mekanis generator (MW)

$P_{\text {mak }}=$ Daya maksimum generator $(\mathrm{MW})$

$\delta_{0} \quad=$ Sudut rotor awal generator (Derajat)

$\delta_{\text {maks }}=$ Sudut rotor maksimum generator (Derajat)

$\delta_{c r} \quad=$ Sudut pemutus kritis (Derajat)

$t_{c r} \quad=$ Waktu pemutus kritis (Detik)

$X^{\prime}{ }_{d} \quad=$ Reaktansi transien generator (p.u)

$X_{T} \quad=$ Reaktansi transformator (p.u)

$X_{L} \quad=$ Reaktansi saluran (p.u)

\section{HASIL DAN PEMBAHASAN}

Sistem interkoneksi merupakan kumpulan dari beberapa pusat tenaga listrik yang dihubungkan oleh suatu jaringan transmisi. Sistem tenaga listrik yang digunakan pada sistem transmisi Riau menggunakan tegangan $150 \mathrm{kV}$. Sistem tenaga listrik di Riau terhubung interkoneksi sistem transmisi sumatera bagian tengah. Sistem transmisi Sumatera bagian tengah yang terdiri dari sistem transmisi $150 \mathrm{kV}$ Sumatera Barat, sistem transmisi Jambi dan sistem transmisi Riau. Sistem interkoneksi ini bertujuan untuk menjaga kestabilan sistem tenaga listrik dalam rangka penyaluran energi listrik menuju pusat beban. Sistem transmisi Riau yang menghubungkan antara pusat tenaga listrik dan gardu induk. Jenis pusat pembangkit listrik yang ada di Riau terdiri dari :

1. Pembangkit Listrik Tenaga Air (PLTA)

2. Pembangkit Listrik Tenaga Uap (PLTU)

3. Pembangkit Listrik Tenaga Diesel (PLTD)

4. Pembangkit Listrik Tenaga Gas (PLTG)

5. Pembangkit Listrik Tenaga Mesin Gas (PLTMG)

Sistem Transimisi Riau dihubungkan melalui saluran udara tegangan tinggi (SUTT). Saluran transmisi ini bertujuan untuk menanggulangi kekurangan daya yang sedang terjadi diwilayah Riau 
sehingga kontinuitas penyaluran daya terjaga. PT. PLN (Persero) Penyaluran dan pusat pengaturan beban (P3B) Riau merupakan unit yang mengelola operasi sistem tenaga listrik dan mengatur beban yang terdapat di Riau. Untuk single line Sistem Transmisi $150 \mathrm{kV}$ Riau seperti pada Gambar 4.

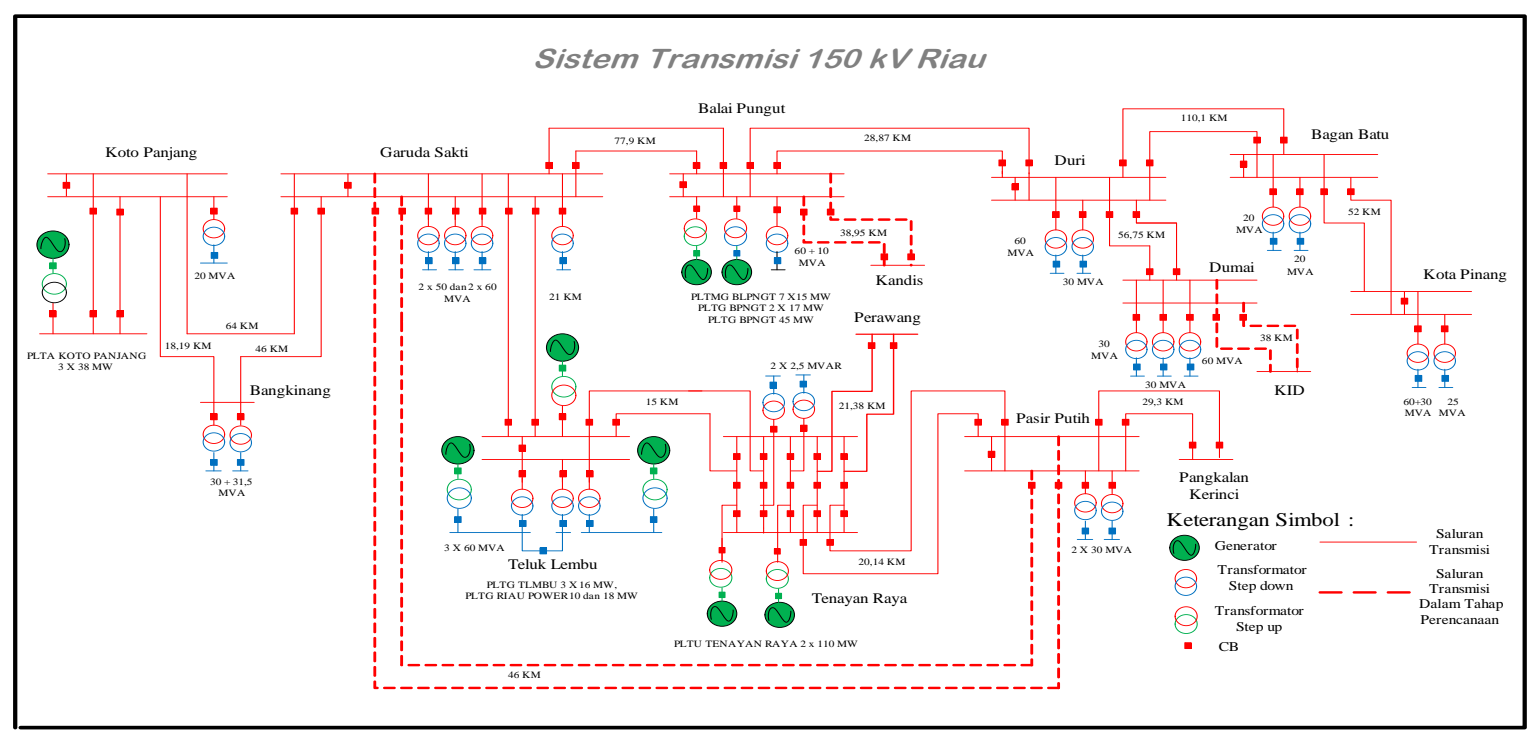

Gambar 4. Single line diagram sistem tenaga listrik riau

\section{Waktu Pemutus Kritis $\left(t_{c r}\right)$ Berdasarkan Metode Kriteria Sama Luas}

Gangguan hubung singkat 3 phasa diasumsikan terjadi pada 2 titik, yaitu : pada titik $0 \%$ dan $50 \%$ dari panjang saluran transmisi. Pada saat gangguan terjadi pada titik $0 \%$ (ujung sisi kirim) dari panjang saluran transmisi dititik $\mathrm{F}$ seperti Gambar 3. Generator Tenayan Raya yang dihubungkan melalui saluran transmisi paralel menuju bus tak terhingga, dimana tegangan pada bus tak terhingga yaitu $1 \angle 0^{0}$ p.u.

Kemudian waktu pemutus kritis saat terjadi gangguan hubung singkat 3 phasa pada saluran Tenayan Raya menuju Teluk Lembu. Dengan sudut kerja awal rotor generator $\delta_{0}=14,2238^{\circ}=0,2468$ radian dan $P_{m}=1,1$ p.u. Pada saat gangguan hubung singkat 3 phasa pada titik F seperti Gambar 3 diperoleh nilai sudut pemutus kritis $\left(\delta_{c r}\right)$ sebesar $108,6266^{\circ}=1,8959$ radian dan untuk waktu pemutus kritis $\left(t_{c r}\right)$ sebesar 0,29 detik.

Hasil perhitungan sudut dan waktu pemutus kritis dengan program matlab didapatkan seperti pada Gambar 5 dan kurva kriteria sama luas untuk menentukan sudut pemutus kritis seperti Gambar 6 .

$=====================================$
$==\quad$ SUDUT DAN WAKTU PEMUUS KRITIS $==$
$==\quad$ METODE KRTERIA SAMA LUAS $==$
$=======================================$
$=$ Sudut pemutus kritis $=108.6289$ derajat $=$
$=\quad$ Waktu pemutus kritis $=0.29001$ detik =
$========================================$

Gambar 5. Perhitungan waktu dan sudut pemutus kritis menggunakan matlab

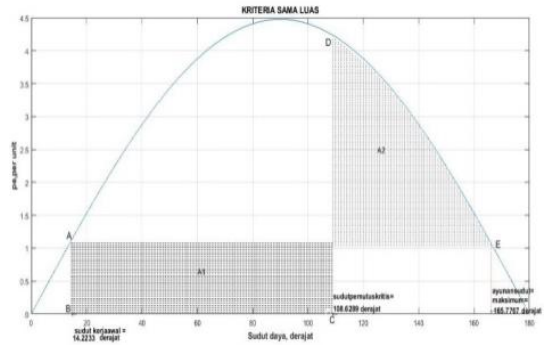

Gambar 6. Kriteria sama luas untuk gangguan pada ujung sisi kirim

Dari hasil simulasi menggunakan matlab diperoleh nilai sudut pemutus kritis menggunakan metode kriteria sama luas seperti Gambar 6 sebesar $108,6289^{\circ}$ dengan waktu pemutus kritis sebesar 0,29001 detik serta sudut ayunan maksimum sebesar $165,7767^{\circ}$. Dari Gambar 6 terlihat sudut awal rotor pada titik A dimana daya listrik yang ditransfer sebesar 1,1 p.u. Pada saat terjadi gangguan hubung singkat 3 phasa sudut awal rotor maju dari $\delta_{0}$ menuju sudut pemutus kritis $\delta_{c r}$ yang artinya berubah dari titik $\mathrm{B}$ menuju titik $\mathrm{C}$ dan daya listrik yang ditransfer sama dengan 0 . Jika gangguan hubung singkat 3 phasa dihilangkan pada sudut $\delta_{c r}$ keluaran daya listrik berubah dan naik menuju titik D. Akibatnya kecepatan rotor generator menurun $P_{e}$ (daya listrik) berubah dari titik D menuju titik E. Lalu kecepatan rotor generator kembali serempak meskipun sudut rotor generator telah maju sampai $\delta_{\text {mak }}$ yaitu $165,7767^{\circ}$.

Pada saat gangguan hubung singkat 3 phasa terjadi dititik $50 \%$ dari panjang saluran pada titik $\mathrm{F}$ seperti Gambar 4, diperoleh nilai sudut pemutus kritis $\left(\delta_{c r}\right)$ sebesar $163,1170^{\circ}=2,8469$ radian dan untuk waktu pemutus kritis $\left(t_{c r}\right)$ sebesar 0,3641 detik. 
Kemudian perhitungan sudut dan waktu pemutus kritis dengan program matlab didapatkan hasil seperti pada Gambar 7 dan kurva kriteria sama luas untuk menentukan sudut pemutus kritis seperti Gambar 8.

$=====================================$
$==\quad$ SUDUT DAN WAKTU PEMUUS KRITIS $==$
$==\quad$ METODE KRITERIA SAMA LUAS $==$
$======================================$
$=$ Sudut pemutus kritis $=162.977$ derajat $=$
$=$ Waktu pemutus kritis $=0.36404$ detik =
$=======================================$

Gambar 7. Perhitungan waktu dan sudut pemutus kritis menggunakan matlab

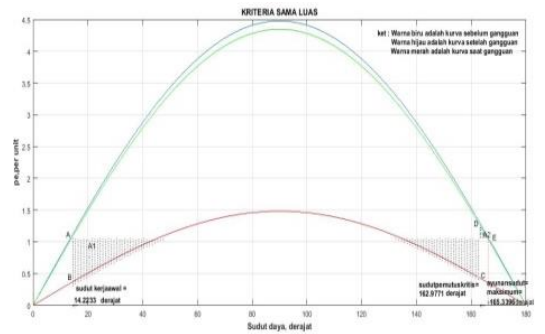

Gambar 8. Kriteria sama luas untuk gangguan pada tengah saluran

Dari hasil simulasi menggunakan matlab diperoleh nilai sudut pemutus kritis menggunakan metode kriteria sama luas seperti Gambar 8 sebesar $162,9771^{\circ}$ dengan waktu pemutus kritis sebesar 0,36404 detik serta sudut ayunan maksimum sebesar $165,3396^{\circ}$. Dari Gambar 8 terlihat sudut awal rotor pada titik A dimana daya listrik yang ditransfer sebesar 1,1 p.u. Pada saat terjadi gangguan hubung singkat 3 phasa sudut awal rotor maju dari $\delta_{0}$ menuju sudut pemutus kritis $\delta_{c r}$ yang artinya berubah dari titik B menuju titik C. Jika gangguan hubung singkat 3 phasa dihilangkan pada sudut $\delta_{c r}$ keluaran daya listrik berubah dan naik menuju titik D. Akibatnya kecepatan rotor generator menurun $P_{e}$ (daya listrik) berubah dari titik D menuju titik E. Lalu kecepatan rotor genarator kembali serempak meskipun sudut rotor generator telah maju sampai $\delta_{\text {mak }}$ yaitu $165,3396^{\circ}$.

\section{Simulasi Menggunakan Powerworld Simulator}

Pada saat simulasi menggunakan Powerworld Simulator untuk sudut rotor generator Tenayan pada saat sistem beroperasi normal tanpa gangguan seperti Gambar 9.

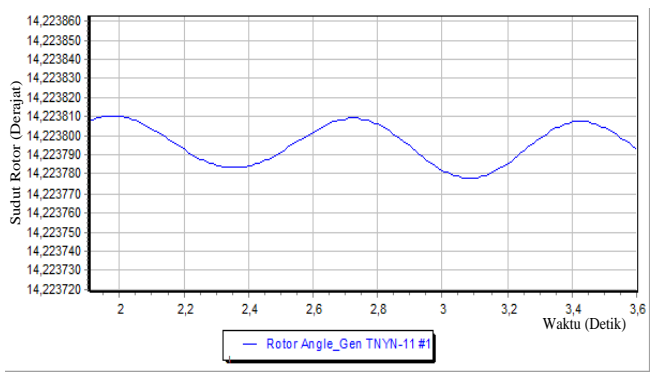

Gambar 9. Sudut rotor generator tenayan pada saat kondisi normal

Gambar 9 merupakan hasil simulasi sudut rotor generator Tenayan dalam keadaan normal tanpa gangguan menggunakan powerworld simulator. Terlihat sudut awal kerja rotor generator Tenayan Raya berada pada $14,2238^{\circ}$ pada saat keadaan normal.

Dalam melakukan simulasi studi kasus kestabilan transien ini dibuat suatu skenario gangguan hubung singkat 3 phasa pada saluran Tenayan menuju Teluk Lembu untuk melihat perubahan sudut rotor generator dan menilai kondisi sistem apakah masih stabil, dengan gangguan hubung singkat 3 phasa terjadi pada ujung sisi kirim dan saat gangguan berada jauh dari ujung sisi kirim, dengan waktu pemutus kritis 0,29 detik. Lalu dilakukan simulasi dengan waktu pemutus secara acak setelah gangguan terjadi untuk melihat kondisi sistem serta mengetahui batas maksimum waktu pemutus.

Gangguan Hubung Singkat 3 Phasa Pada Jarak 0\% Dengan $\boldsymbol{t}_{\boldsymbol{c r}}=\mathbf{0 , 2 9}$ Detik

Setelah didapatkan waktu pemutus kritis maka dilakukan simulasi gangguan hubung singkat 3 phasa pada jarak 0\% saluran Tenayan Raya menuju Teluk Lembu dengan waktu pemutus kritis 0,29 detik setelah gangguan bekerja maka respon sudut generator Tenayan seperti pada Gambar 10.

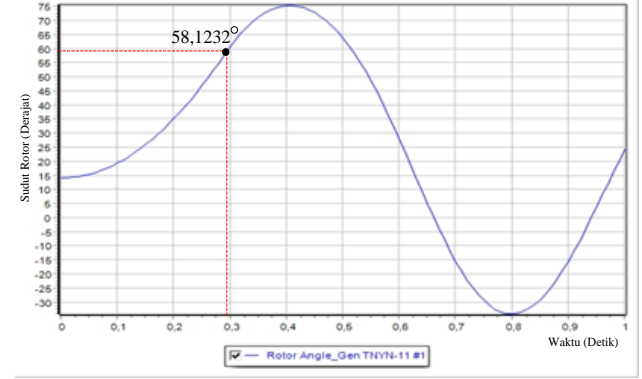

Gambar 10. Waktu pemutus kritis 0,29 detik

Gambar 10 menunjukkan respon sudut generator saat terjadi gangguan hubung singkat 3 phasa pada saluran yang menghubungkan GI Tenayan menuju GI Teluk Lembu. Lalu waktu pemutus kritis yang telah dihitung dimasukan kedalam simulasi untuk memutuskan gangguan. Kemudian terlihat terjadinya ayunan pada saat waktu pemutus 0,29 detik setelah gangguan terjadi. Hasil simulasi menggunakan Powerworld Simulator sistem masih stabil karena grafik menunjukkan terjadinya ayunan dan didapatkan sudut pemutus sebesar $58,1232^{\circ}$ lebih kecil dari sudut pemutus kritis sebesar $108,6266^{\circ}$.

Kemudian respon sudut rotor generator pada sistem tenaga listrik Riau pada saat terjadi gangguan hubung singkat 3 phasa pada saluran Tenayan 
menuju Teluk Lembu dengan waktu pemutus kritis 0,29 detik setelah gangguan seperti pada Gambar 11 .

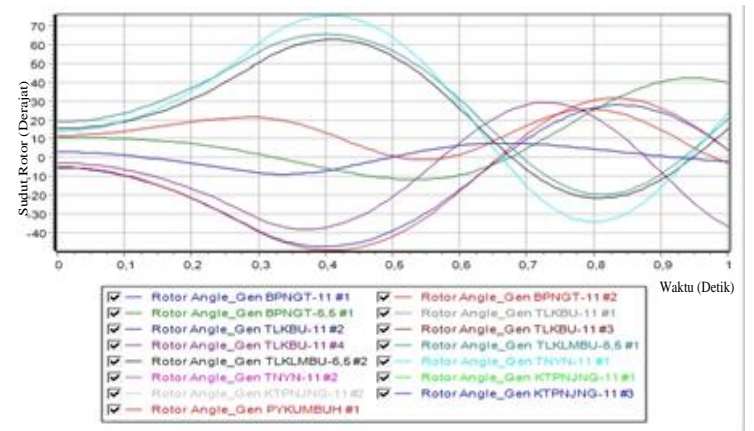

Gambar 11. Waktu pemutus kritis 0,29 detik

Gambar 11 menunjukkan respon sudut rotor generator pada saat terjadi gangguan 3 phasa pada saluran Tenayan menuju Teluk Lembu. Masingmasing generator mengalami osilasi dan perubahan sudut rotor cukup besar. Respon sudut rotor dari generator Tenayan yang mempunyai sudut rotor normal sebelum gangguan yaitu $14,2238^{\circ}$ kemudian setelah gangguan mengalami perubahan dengan nilai sudut rotor maksimum sebesar $75,354^{\circ}$ pada detik ke 0,410 sedangkan sudut rotor minimum setelah gangguan $-34,004^{\circ}$ pada detik ke 0,8 .

Lalu dilakukan percobaan dengan waktu pemutus berbeda lebih lambat yaitu 0,36 detik setelah gangguan bekerja untuk melihat respon sudut generator, lalu respon sudut rotor generator Tenayan dengan $t_{c r}=0,36$ detik pada Gambar 12 .

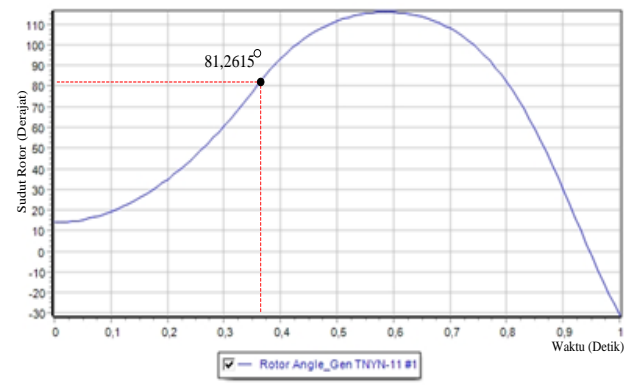

Gambar 12. Waktu pemutus kritis 0,36 detik

Gambar 12 menunjukkan respon sudut generator saat terjadi gangguan hubung singkat 3 phasa pada saluran Tenayan menuju Teluk Lembu. Dengan waktu pemutus 0,36 detik setelah gangguan terjadi sistem masih stabil. Hasil simulasi menggunakan Powerworld Simulator menunjukkan terjadinya ayunan sudut rotor dan didapatkan sudut pemutus sebesar $81,2615^{\circ}$ lebih kecil dari sudut pemutus kritis sebesar $108,6266^{\circ}$.

Lalu dilakukan percobaan dengan waktu pemutus berbeda dan lebih lambat yaitu 0,37 detik setelah gangguan bekerja untuk melihat respon sudut generator, lalu respon sudut rotor generator Tenayan dengan $t_{c r}=0,37$ detik pada Gambar 13 .

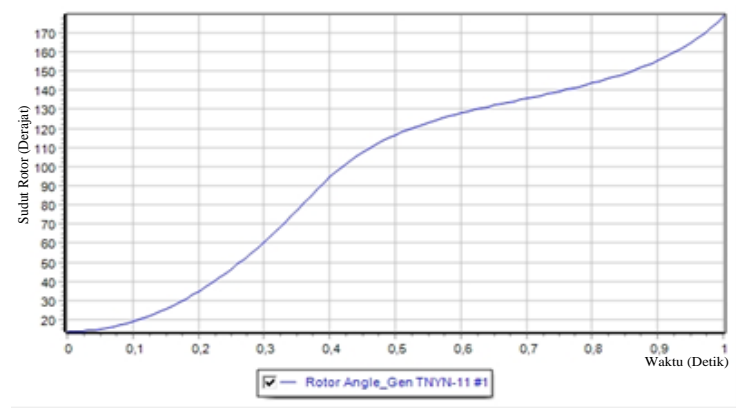

Gambar 13. Waktu pemutus kritis 0,37 detik

Gambar 13 menunjukan respon sudut generator saat terjadi gangguan hubung singkat 3 phasa pada saluran Tenayan menuju Teluk Lembu. Dengan waktu pemutus 0,37 detik setelah gangguan terjadi sistem tidak stabil. Hasil simulasi menggunakan Powerworld Simulator menunjukkan tidak terjadinya ayunan sudut rotor.

Kemudian respon sudut rotor generator pada sistem UPT Pekanbaru pada saat terjadi gangguan hubung singkat 3 phasa pada saluran Tenayan menuju Teluk Lembu dengan waktu pemutus kritis 0,37 detik setelah gangguan seperti pada Gambar 14 .

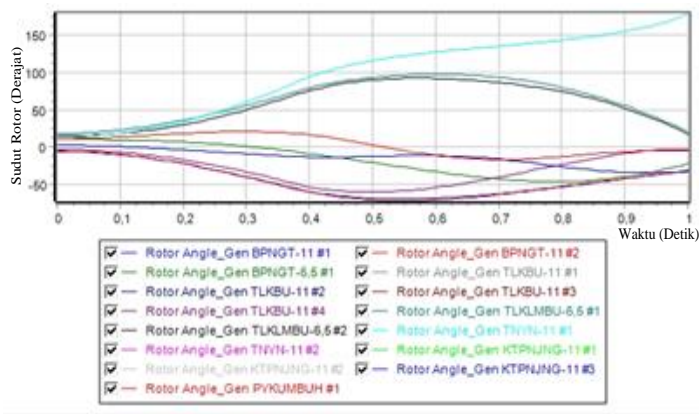

Gambar 14. Waktu pemutus kritis 0,37 detik

Gambar 14 menunjukan respon sudut rotor generator pada saat terjadi gangguan 3 phasa pada saluran Tenayan menuju Teluk Lembu. Dengan waktu pemutus gangguan 0,37 detik setelah gangguan. Masing-masing generator mengalami osilasi dan perubahan sudut rotor sangat besar. Dengan waktu pemutus 0,37 detik setelah gangguan terjadi sistem tidak stabil. Hasil simulasi menggunakan Powerworld Simulator menunjukkan tidak terjadinya ayunan sudut rotor.

\section{Gangguan Hubung Singkat 3 Phasa Pada Jarak $50 \%$ Dengan $t_{c r}=0,3641$ Detik}

Setelah didapatkan waktu pemutus kritis maka dilakukan simulasi gangguan hubung singkat 3 phasa pada jarak 50\% saluran Tenayan Raya menuju Teluk Lembu dengan waktu pemutus kritis 0,3641 
detik setelah gangguan bekerja maka respon sudut generator Tenayan seperti pada Gambar 15.

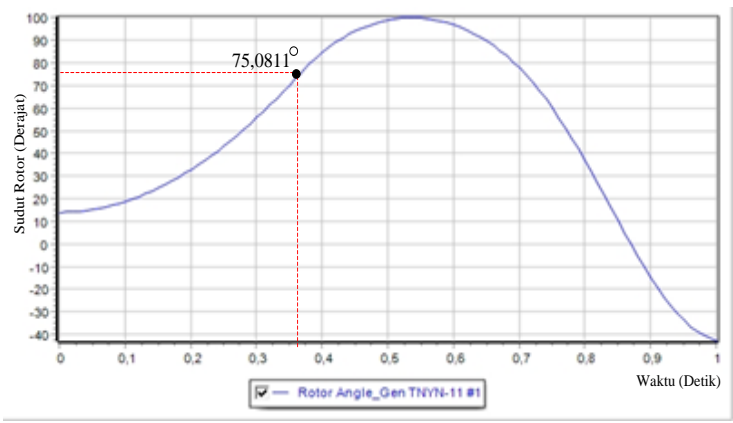

Gambar 15. Waktu pemutus kritis 0,3641 detik

Gambar 15 menunjukkan respon sudut generator saat terjadi gangguan hubung singkat 3 phasa pada saluran Tenayan menuju Teluk Lembu. Lalu waktu untuk pemutus kritis yang telah dihitung dimasukan kedalam simulasi. Terlihat terjadinya ayunan pada saat waktu pemutus 0,3641 detik setelah gangguan terjadi. Hasil simulasi menggunakan Powerworld Simulator maka sistem masih stabil karena grafik menunjukkan terjadinya ayunan dan didapatkan sudut pemutus sebesar $75,0811^{\circ}$ lebih kecil dari sudut pemutus kritis sebesar $163,1170^{\circ}$.

Kemudian respon sudut rotor generator pada sistem UPT Pekanbaru pada saat terjadi gangguan hubung singkat 3 phasa pada saluran Tenayan menuju Teluk Lembu dengan waktu pemutus kritis 0,3641 detik setelah gangguan seperti pada Gambar 16.

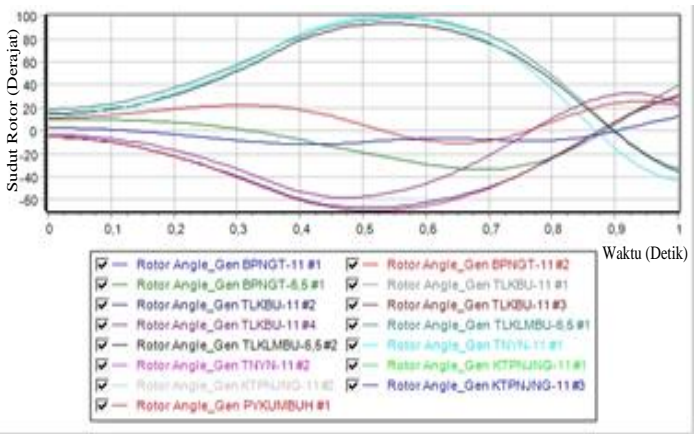

Gambar 16. Waktu pemutus kritis 0,3641 detik

Gambar 16 menunjukkan respon sudut rotor generator pada saat terjadi gangguan 3 phasa pada saluran Tenayan menuju Teluk Lembu. Dengan waktu pemutus 0,3641 detik setelah gangguan terjadi. Masing-masing generator mengalami osilasi dan perubahan sudut rotor cukup besar. Respon sudut rotor dari generator Tenayan Raya yang mempunyai sudut rotor normal sebelum gangguan yaitu $14,2238^{\circ}$ Kemudian setelah gangguan mengalami perubahan dengan nilai sudut rotor maksimum sebesar $100,209^{\circ}$ pada detik ke 0,540 sedangkan sudut rotor minimum setelah gangguan $42,511^{\circ}$ pada detik ke 0,1 .

Lalu dilakukan percobaan dengan waktu pemutus berbeda dan lebih lambat yaitu 0,37 detik setelah gangguan bekerja untuk melihat respon sudut generator, lalu respon sudut rotor generator Tenayan dengan $t_{c r}=0,37$ detik seperti pada Gambar 17 .

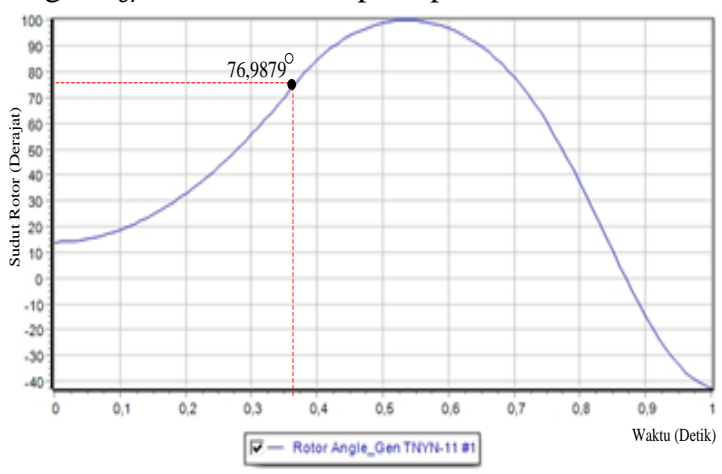

Gambar 17. Waktu pemutus kritis 0,37 detik

Gambar 17 menunjukan respon sudut generator saat terjadi gangguan hubung singkat 3 phasa pada saluran Tenayan menuju Teluk Lembu. Dengan waktu pemutus 0,37 detik setelah gangguan terjadi sistem masih stabil. Hasil simulasi menggunakan Powerworld Simulator menunjukkan terjadinya ayunan sudut rotor dan didapatkan sudut pemutus sebesar $76,9879^{\circ}$ lebih kecil dari sudut pemutus kritis sebesar $163,1170^{\circ}$.

Lalu dilakukan percobaan dengan waktu pemutus berbeda dan lebih lambat yaitu 0,39 detik setelah gangguan bekerja untuk melihat respon sudut generator, lalu respon sudut rotor generator Tenayan dengan $t_{c r}=0,39$ detik pada Gambar 18 .

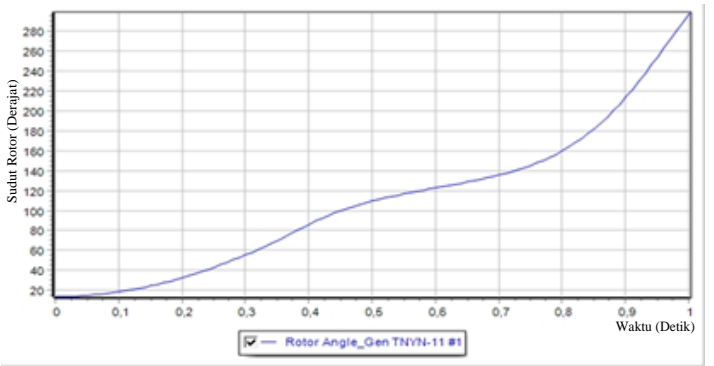

Gambar 18. Waktu pemutus kritis 0,39 detik

Gambar 18 menunjukkan respon sudut generator saat terjadi gangguan hubung singkat 3 phasa pada saluran Tenayan menuju Teluk Lembu. Dengan waktu pemutus 0,39 detik setelah gangguan terjadi sistem tidak stabil. Hasil simulasi menggunakan Powerworld Simulator menunjukkan tidak terjadinya ayunan sudut rotor.

Kemudian respon sudut rotor generator pada sistem UPT Pekanbaru pada saat terjadi gangguan hubung singkat 3 phasa pada saluran Tenayan menuju Teluk Lembu dengan waktu pemutus kritis 0,39 detik setelah gangguan seperti pada Gambar 19 . 


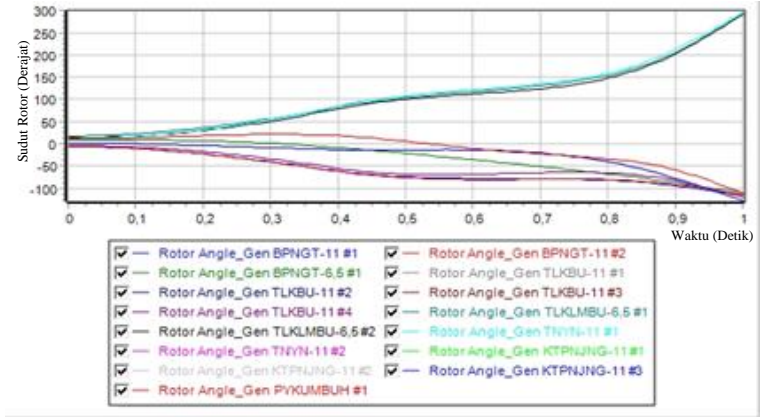

Gambar 19. Waktu pemutus kritis 0,39 detik

Gambar 19 menunjukkan respon sudut rotor generator pada saat terjadi gangguan 3 phasa pada saluran Tenayan menuju Teluk Lembu. Dengan waktu pemutus gangguan 0,39 detik setelah gangguan. Masing-masing generator mengalami osilasi dan perubahan sudut rotor sangat besar. Dengan waktu pemutus 0,39 detik setelah gangguan terjadi sistem tidak stabil. Hasil simulasi menggunakan Powerworld Simulator menunjukkan tidak terjadinya ayunan sudut rotor.

Setelah dilakukan perhitungan waktu dan sudut pemutus kritis pada saat terjadi gangguan hubung singkat 3 phasa pada saluran Tenayan Raya menuju Teluk Lembu. Lalu dengan cara yang sama dilakukan perhitungan waktu dan sudut pemutus kritis Tenayan Raya menuju Perawang dan Tenayan Raya menuju Pasir Putih seperti pada Tabel 1.

Tabel 1. Perhitungan waktu dan sudut pemutus kritis

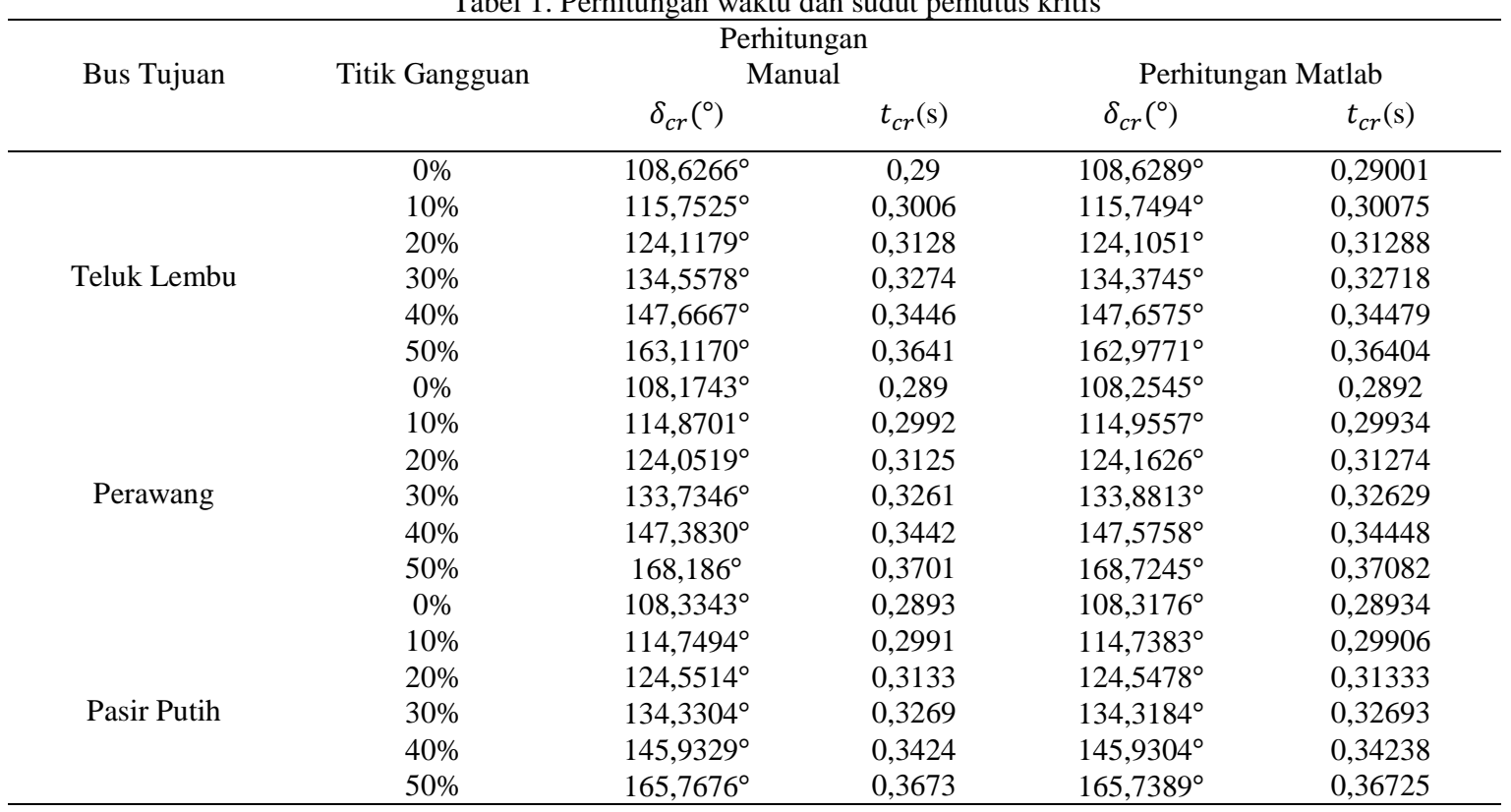

Dari Tabel 1 diperoleh grafik waktu pemutus kritis dan sudut pemutus kritis berdasarkan titik gangguan hubung singkat 3 phasa pada saluran Tenayan Raya

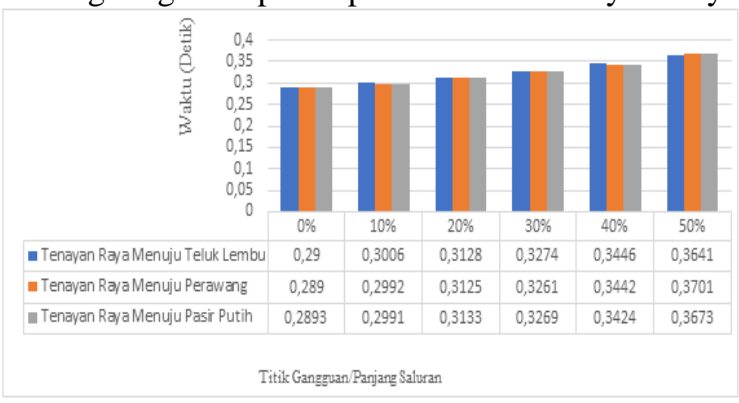

Gambar 20. Grafik waktu pemutus kritis berdasarkan titik gangguan

Gambar 20 dan 21 merupakan perbandingan sudut dan waktu pemutus kritis berdasarkan titik gangguan hubung singkat 3 phasa pada saluran Tenayan Raya menuju Teluk Lembu, Tenayan Raya menuju Teluk Lembu, Tenayan Raya menuju Perawang dan Tenayan Raya menuju Pasir Putih seperti Gambar 20 dan 21.

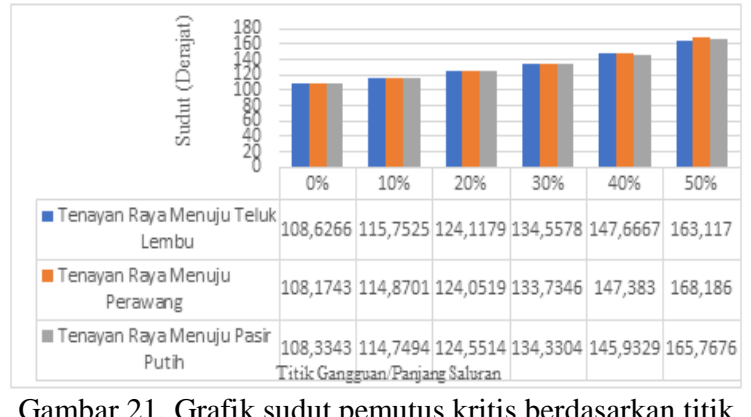

Gambar 21. Grafik sudut pemutus kritis berdasarkan titik gangguan

menuju Perawang dan Tenayan Raya menuju Pasir Putih. Terlihat pada grafik, semakin jauh titik gangguan maka sudut dan waktu pemutus kritis semakin besar. 


\section{KESIMPULAN}

Dari hasil perhitungan nilai sudut kerja awal generator Tenayan Raya sebesar $14,2238^{\circ}$, untuk sudut pemutus kritis $108,6266^{\circ}=1,8959$ radian dan nilai waktu pemutus kritis 0,29 detik untuk gangguan hubung singkat 3 phasa pada ujung sisi kirim saluran transmisi.

Setelah dilakukan simulasi menggunakan powerworld pada saluran Tenayan menuju Teluk Lembu saat gangguan hubung singkat 3 phasa terjadi pada jarak $0 \%$ dengan waktu pemutus kritis 0,29 dan 0,36 detik sistem masih stabil karena grafik respon sudut rotor menunjukkan terjadinya ayunan, lalu sistem tidak stabil pada waktu pemutus 0,37 detik setelah gangguan terjadi.

Setelah dilakukan simulasi menggunakan powerworld pada saluran Tenayan menuju Teluk Lembu saat gangguan hubung singkat 3 phasa terjadi pada jarak $50 \%$ dengan waktu pemutus kritis 0,3641 dan 0,37 detik sistem masih stabil karena grafik respon sudut rotor menunjukkan terjadinya ayunan, lalu sistem tidak stabil pada waktu pemutus 0,39 detik setelah gangguan terjadi.

Semakin jauh titik gangguan pada saluran transmisi maka sudut dan waktu pemutus kritis semakin besar.

\section{DAFTAR PUSTAKA}

[1] H. Hendry, H. Eteruddin, and A. Atmam, "Analysis of Voltage Sag Due to Short Circuit on the Sub System in Central Sumatera," Int. J. Electr. Energy Power Syst. Eng., vol. 1, no. 2, pp. 1-5, 2018.

[2] Badan Pusat Statistik Provinsi Riau, "Jumlah Penduduk Menurut Kabupaten / Kota di Provinsi Riau, 2010-2019,” 2020. [Online]. Available: https://riau.bps.go.id/dynamictable/2016/10/ 03/6/jumlah-penduduk-menurut-kabupatenkota-di-provinsi-riau-2011-2017.html.

[3] Nolpitos Hendri, "Live Streamins: PLN Ungkap Riau Masih Kekurangan Daya Listrik 270 MW," Tribunpekanbaru.com, Pekanbaru, Mar-2018.

[4] H. Eteruddin and A. A. Mohd Zin, "Analisis Penambahan Pembangkit Baru dan Gardu Induk di Tenayan Raya, terhadap Sistem Kelistrikan Riau," in Applied Engineering Seminar (AES), 2010.

[5] H. Eteruddin and A. A. Mohd Zin, "Pengaruh Penambahan Gardu lnduk Tenayan Raya terhadap Sistem Kelistrikan Sumbar - Riau - Jambi," in Seminar Nasional Teknologi Informasi Komunikasi dan Industri (SNTIKI) 2, 2010.

[6] H. Eteruddin and A. A. Mohd Zin, "Dampak Pembangunan Pembangkit 2 x 100 MVA dan Gardu Induk 150 kV di Tenayan Raya terhadap Sistem Kelistrikan Riau," in Seminar Nasional Pengkajian dan Penerapan Teknologi Industri, 2010, pp. 173-178.

[7] H. Eteruddin and A. A. Mohd Zin, "Pengaruh Penambahan Gardu Induk Tenayan Raya terhadap Sistem Kelistrikan Sumbar - Riau," in Seminar Nasional 2 Teknologi dan Rekayasa (SN2TR), 2010.

[8] H. Eteruddin, D. Setiawan, and H. P. Sitepu, "Modifikasi Sistem ATS-AMF Diesel Emergency Generator Pada PLTU dengan Metode Warming Up," J. Tek., vol. 14, no. 2, pp. 129-136, 2020.

[9] H. Eteruddin, A. A. Mohd Zin, and B. Belyamin, "Line Differential Protection Modeling with Composite Current and Voltage Signal Comparison Method," Telkomnika, vol. 12, no. 1, Mar. 2014.

[10] P. Kundur, Power System Stability And Control. New York: McGraw-Hill, 1994.

[11] L. L. Grigsby, Power System Stability and Control, 3rd ed. Boca Raton: CRC Press, 2017.

[12] C. W. Taylor, "Power System Stability and Control," 2006.

[13] P. Kundur, J. Paserba, V. Vittal, and G. Anderson, "Definition and Classification of Power System Stability," IEEE Trans. Power Syst., vol. 21, no. 1, p. 15, 2004.

[14] J. J. Grainer and W. D. Stevenson Jr, Power System Analysis, 5th ed. New York: McGraw-Hill, 1994.

[15] J. R. N. Chiappin and M. J. de Oliveira, "Emergence of cooperation among interacting individuals," Phys. Rev. E - Stat. Physics, Plasmas, Fluids, Relat. Interdiscip. Top., vol. 59, no. 6, pp. 6419-6421, 1999.

[16] N. Jenkins et al., Embedded Generation. London: The Institution of Engineering and Technology, 2000.

[17] C. Cekdin, Sistem Tenaga Listrik, Kedua. Yogyakarta: Andi Offset, 2007. 